\title{
Huellas del territorio en las prácticas pre-profesionales: construcción de identidades y autonomías
}

\author{
D’Angelo, Marcela S.; Donayo, Florencia C.; Heinrich, Verónica T.
}

\section{Resumen}

La Licenciatura de Terapia Ocupacional de la Universidad Nacional del Litoral, contempla en su plan de estudio seis espacios de Prácticas Pre-profesionales, que permiten a los estudiantes tener una experiencia de aprendizaje situado. El presente trabajo pretende compartir reflexiones realizadas por el equipo docente que integra la "Práctica Pre-Profesional VI de Terapia Ocupacional en comunidad, al efectuar un análisis cuali-cuantitantivo de noventa y seis (96) trabajos finales realizados por estudiantes al finalizar el proceso de la práctica desde el año 2002, cuando se incorpora esta asignatura a la propuesta curricular, hasta la fecha.

Los trabajos analizados dan cuenta de la multiplicidad de propuestas en las que se han incluído practicantes permitiendo identificar tres ejes temáticos en torno a los cuales los estudiantes han narrado sus reflexiones: la construcción del rol profesional en el campo social; la otredad y la ocupación como medio terapéutico para la promoción de la salud.

Las narrativas muestran los principales desafíos que en el trayecto formativo se nos plantean a estudiantes y docentes de la práctica pre-profesional en el campo comunitario, por cuanto el proceso de acompañar a aquellos en la búsqueda de la autonomía, no puede ir sin el ejercicio de la propia autonomía.

Palabras clave: identidad profesional, otredad, autonomía. 


\section{Summary}

Traces of the territory in the pre-professional construction of identities and autonomies

The Master of Occupational Therapy of the National University of the Littoral, he contemplates in his plan of study six spaces of Pre-professional Practices, which allow to the students to have an experience of placed learning. The present work tries to share reflections realized by the educational equipment that integrates the "Pre-professional Practice the VIth of Occupational Therapy in community, on having effected an analysis cuali-cuantitantivo of ninety six (96 final works realized by students on having finished the process of the practice from the year 2002, when this subject joins to the offer curricular, up to the date.

The analyzed works realize of the multiplicity of offers in those who included medical instructors; as well as they have allowed to identify three thematic axes concerning which the students have narrated his reflections: the construction of the professional role in the social field; the otherness and the occupation like therapeutic way for the promotion of the health.

The narratives show the principal challenges that in the formative distance us appear to students and teachers of the pre-professional practice in the community field, since the process of accompanying those in the search of the autonomy, cannot go without the exercise of the own autonomy.

Keywords: professional identity, otherness, autonomy. 